\title{
Milankovitch-paced Termination II in a Nevada speleothem?
}

\author{
Jeremy D. Shakun, ${ }^{1}$ Stephen J. Burns, ${ }^{2}$ Peter U. Clark, ${ }^{3}$ Hai Cheng, ${ }^{4,5}$ \\ and R. Lawrence Edwards ${ }^{5}$ \\ Received 20 June 2011; revised 18 August 2011; accepted 20 August 2011; published 17 September 2011.
}

[1] The Devils Hole (DH) calcite record from the Great Basin, Nevada, provided the first radiometrically dated time series of late-Pleistocene climate fluctuations,. In doing so, DH suggested that the penultimate deglaciation, Termination II (T-II), occurred at $142 \pm 3 \mathrm{ka}$, which is $\sim 10 \mathrm{kyr}$ before the associated rise in summer insolation, helping to launch the "causality problem" for Milankovitch. The interpretation of the DH record has been subject to considerable discussion ever since. We present the first attempt to reproduce the DH record of an early T-II in the Great Basin based on a stalagmite from Lehman Caves, Nevada, which is $\sim 400 \mathrm{~km}$ northeast of Devils Hole. Our speleothem records at least the latter part of T-II over its period of growth from $\sim 133-129 \mathrm{ka}$, which appears to disagree with the early timing of T-II in DH. DH also exhibits important differences from many other paleoclimate records over the past two deglaciations, though these are reduced somewhat after ice-volume correcting $\mathrm{DH} \delta^{18} \mathrm{O}$. We suggest that the climatic signal in the DH record remains to be fully explained. Citation: Shakun, J. D., S. J. Burns, P. U. Clark, H. Cheng, and R. L. Edwards (2011), Milankovitch-paced Termination II in a Nevada speleothem?, Geophys. Res. Lett., 38, L18701, doi:10.1029/2011GL048560.

\section{Introduction}

[2] The Devils Hole (DH) vein-calcite $\delta^{18} \mathrm{O}$ record from the Great Basin of Nevada is one of the most well-known and controversial paleoclimate records. It provided the first radiometrically dated time series of late-Pleistocene climate variations, and these first results were thought to raise a major challenge to the Milankovitch theory [Winograd et al., 1988, 1992]. In particular, DH placed the penultimate deglaciation, Termination II (T-II), at $142 \pm 3 \mathrm{ka}$, which is $\sim 10 \mathrm{kyr}$ before the associated rise in insolation, forming the basis of the "causality problem" for Milankovitch [Karner and Muller, 2000]. Considerable debate ensued over the validity of the Milankovitch theory [Broecker, 1992; Edwards and Gallup, 1993; Emiliani, 1993; Imbrie et al., 1993; Johnson and Wright, 1989; Landwehr et al., 1994;

\footnotetext{
${ }^{1}$ Department of Earth and Planetary Sciences, Harvard University, Cambridge, Massachusetts, USA.

${ }^{2}$ Department of Geosciences, University of Massachusetts Amherst, Amherst, Massachusetts, USA.

${ }^{3}$ Department of Geosciences, Oregon State University, Corvallis, Oregon, USA.

${ }^{4}$ Institute of Global Environmental Change, Xi'an Jiaotong University, Xi'an, China.

${ }^{5}$ Department of Geology and Geophysics, University of Minnesota, Twin Cities, Minneapolis, Minnesota, USA.

Copyright 2011 by the American Geophysical Union. 0094-8276/11/2011GL048560
}

Ludwig et al., 1993; Winograd and Coplen, 1989], and the causality problem remains a major focus of research [Cheng et al., 2009; Drysdale et al., 2009; Thomas et al., 2009]. More recently, it has been suggested that the DH record reflects Pacific sea surface temperatures (SSTs), rather than ice volume, and may therefore not pose a problem for a Milankovitch control on glacial cycles [Herbert et al., 2001; Lea et al., 2000; Winograd et al., 1997, 2006]. Questions also surround the geographic significance of the DH signal [Herbert et al., 2002; Winograd, 2002], with suggestions ranging from regional [Herbert et al., 2001] to interhemispheric [Winograd et al., 2006] in scale. Given the historical and continued importance of the DH record in our understanding of late-Pleistocene climate, it is notable that other Great Basin calcite records have not been developed to verify its interpretation. Here we address this issue by developing a brief but well-dated $\delta^{18} \mathrm{O}$ record from a stalagmite (LC-2) from Lehman Caves, Nevada, and examining the hypothesis that DH records Great Basin precipitation isotopes related to Pacific SSTs.

\section{Methods}

[3] Stalagmite LC-2 was collected in June 2004 from Lehman Caves in Great Basin National Park, Nevada, which is $\sim 400 \mathrm{~km}$ northeast of DH (Figure 1). It was sliced in half lengthwise and its interior surfaces were polished (Figure 2d). We obtained $18{ }^{230} \mathrm{Th}$ ages along the $60-\mathrm{cm}$ length of the stalagmite on the University of Minnesota Isotope single MasCom multiplier in peak-jumping mode. Approximately $200 \mathrm{mg}$ of calcite were used for each date. We also measured 53 stable isotope samples along the LC-2 growth axis at $\sim 1-\mathrm{cm}$ resolution using a Finnegan Delta XL ratio mass spectrometer coupled to an automated carbonate preparation system at the University of Massachusetts Stable Isotope Laboratory. Stable isotope samples weighed $\sim 100 \mu \mathrm{g}$ and were collected with a $0.5 \mathrm{~mm}$ carbide dental burr. Analytical precision is $\pm 0.11 \%$ for $\delta^{18} \mathrm{O}$ and $\pm 0.07 \%$ for $\delta^{13} \mathrm{C}$.

\section{Results}

[4] ${ }^{230}$ Th ages span $133.5-126.5 \mathrm{ka}$ and have an average $2 \sigma$ error of $0.6 \mathrm{kyr}$ (Figure 2a and auxiliary material). ${ }^{1}$ All ages but one are in stratigraphic order within error. We created an age model by fitting a 4th-order polynomial through the ages excluding the topmost one and the one that is out of order. The conclusions presented below are insensitive to the choice of age model. Initial thorium corrections are negligible. The LC- $2 \delta^{18} \mathrm{O}$ record is dominated by a secular increase of nearly $2 \%$, whereas the $\delta^{13} \mathrm{C}$ record is nearly

\footnotetext{
${ }^{1}$ Auxiliary materials are available in the HTML. doi:10.1029/ 2011GL048560.
} 


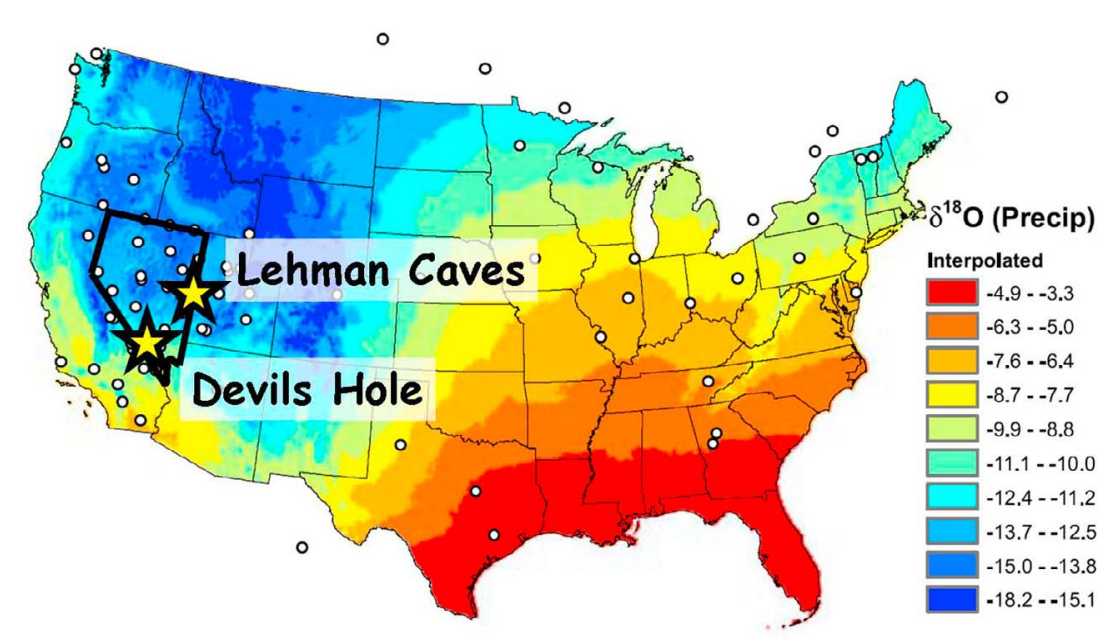

Figure 1. Location of Lehman Caves and Devils Hole in Nevada. The map displays modern weighted mean annual precipitation $\delta^{18} \mathrm{O}$ over the United States (modified from Bowen et al. [2007]).

flat and uncorrelated with $\delta^{18} \mathrm{O}\left(\mathrm{r}^{2}=0.0001\right)$ (Figures $2 \mathrm{~b}, 2 \mathrm{c}$, and $2 \mathrm{e}$ and auxiliary material), suggesting that the isotope record has not been compromised by disequilibrium effects.

[5] Three observations suggest that LC- $2 \delta^{18} \mathrm{O}$ records T-II. First, a $\delta^{18} \mathrm{O}$ value of $-11.3 \%$ on modern calcite from an active stalagmite adjacent to LC-2 is slightly lower than the highest values seen near the end of the LC-2 record (Figure 3f), consistent with LC-2 reaching full interglacial conditions following the termination. Additionally, we note that although the isotopic shift recorded by LC-2 may be larger since there is no plateau near the beginning of the record, the observed $2 \%$ amplitude is nearly identical to that seen in terminations in $\mathrm{DH} \delta^{18} \mathrm{O}$, including T-II (Figure 3h). Finally, the $\delta^{18} \mathrm{O}$ shift recorded in LC-2 is centered on $132 \mathrm{ka}$, which is roughly in phase with T-II in the marine $\delta^{18} \mathrm{O}$ record on both depth-derived [Huybers and Wunsch, 2004] and orbitally-tuned (Figure 3i) [Imbrie et al., 1984] age models, well-dated speleothem records from Italy, Israel, and China (Figures 3a, 3c, and 3d) [Bar-Matthews et al., 2003; Cheng et al., 2009; Drysdale et al., 2009], and $\mathrm{O}_{2} / \mathrm{N}_{2}$-dated
Antarctic ice cores (Figure 3e) [Kawamura et al., 2007]. We thus suggest that LC-2 records T-II, or at least its latter part, but up to $10 \mathrm{kyr}$ later than in the $\mathrm{DH}$ record and, interestingly, at a time consistent with Milankovitch forcing.

\section{Discussion}

\subsection{Stalagmite LC-2 and Devils Hole}

[6] Why do the DH and LC-2 records appear to disagree on the timing of T-II in the Great Basin? The 10-kyr offset between them cannot be attributed to dating uncertainties as the offset is over an order of magnitude larger than the uncertainties. Given the integrity of the dating, it is unlikely that the penultimate deglaciation occurred at such different times within the state of Nevada, suggesting that the climate signal in one or both of these records has been compromised by other factors and/or misinterpreted.

[7] LC-2 is a much simpler recorder of climate than Devils Hole. The $60-\mathrm{cm}$ long T-II record in LC-2 is from a cave stalagmite that communicated rapidly with the surface
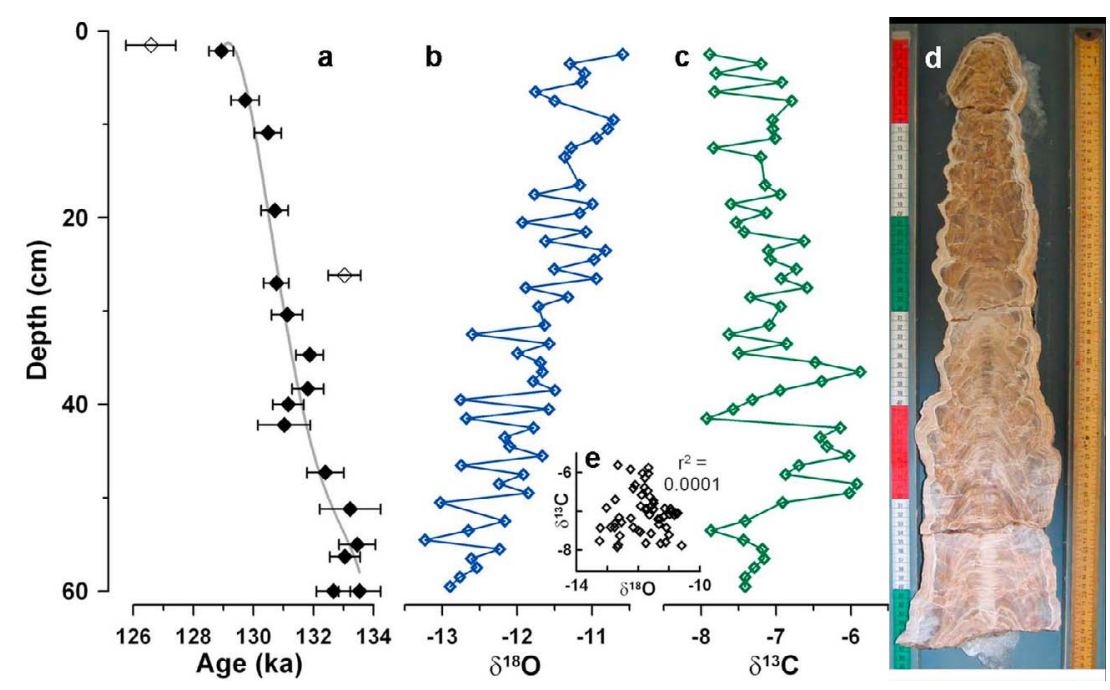

Figure 2. LC-2 data. (a) ${ }^{230} \mathrm{Th}$ dates with $2 \sigma$ errors and age model (gray line). Dates excluded from the age model are shown with open symbols. (b) $\delta^{18} \mathrm{O}$. (c) $\delta^{13} \mathrm{C}$. (d) Photograph of LC-2. (e) Scatterplot of LC-2 $\delta^{18} \mathrm{O}$ versus $\delta^{13} \mathrm{C}$. 


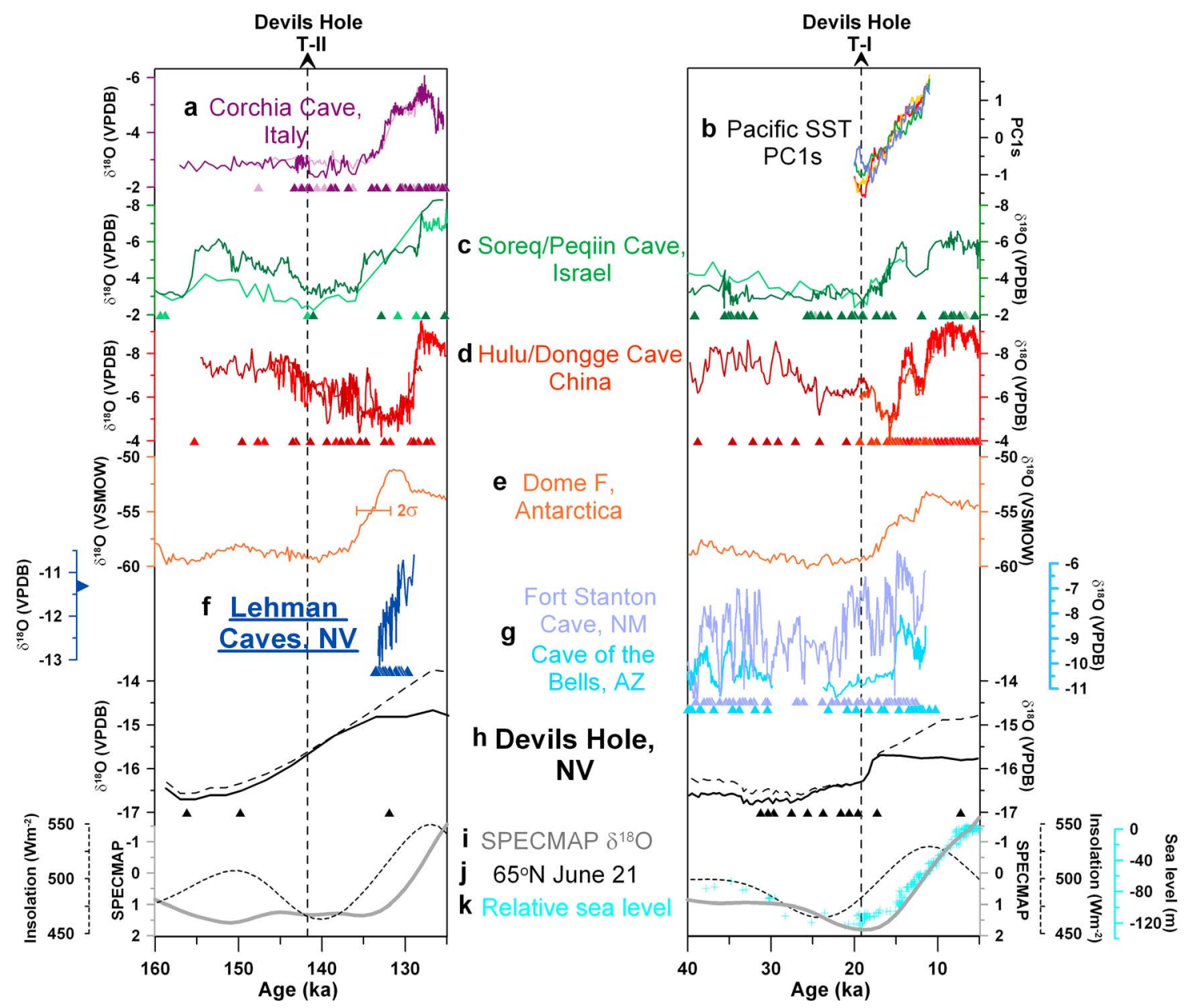

Figure 3. Well-dated records of Terminations (left) I and (right) II. (a) Corchia Cave, Italy speleothem $\delta^{18} \mathrm{O}[$ Drysdale et al., 2009]. (b) PC1s for SST records from the North (blue), eastern tropical (green), western tropical (yellow), and South (red) Pacific (Clark et al., submitted manuscript, 2010). (c) Soreq and Peqiin Caves, Israel speleothem $\delta^{18} \mathrm{O}[$ BarMatthews et al., 2003]. (d) Hulu and Dongge Caves, China speleothem $\delta^{18} \mathrm{O}$ [Wang et al., 2001; Dykoski et al., 2005; Cheng et al., 2006; Kelly et al., 2006]. (e) Dome Fuji, Antarctica $\delta^{18} \mathrm{O}$ [Kawamura et al., 2007]. (f) Lehman Caves, Nevada speleothem LC-2 $\delta^{18} \mathrm{O}$ (this study). (g) Fort Stanton Cave, New Mexico [Asmerom et al., 2010] and Cave of the Bells, Arizona [Wagner et al., 2010] speleothem $\delta^{18} \mathrm{O}$. (h) Uncorrected (solid line) and ice-volume corrected (dashed line) Devils Hole, Nevada $\delta^{18} \mathrm{O}$ [Winograd et al., 1992, 2006]. The ice-volume correction has been zeroed at Last Glacial Maximum values to facilitate comparison of the terminations in the corrected and uncorrected time series. (i) SPECMAC $\delta^{18} \mathrm{O}$ stack [Imbrie et al., 1984]. (j) $65^{\circ} \mathrm{N}$ insolation on June 21 [Laskar et al., 2004]. (k) Coral-based relative sea level record (compilation from Clark et al. [2009]). ${ }^{230}$ Th dates are shown as triangles beneath each speleothem record, and the error associated with the timing of T-II in the $\mathrm{O}_{2} / \mathrm{N}_{2}$-dated Dome Fuji ice core is shown. The triangle on the Lehman Caves, Nevada y-axis shows the $\delta^{18} \mathrm{O}$ of modern calcite. The midpoints of T-I and T-II in the DH record are designated by the vertical dashed lines.

and was fed by local rainfall. Furthermore, stalagmites from this region appear to faithfully record Northern Hemisphere warming events, as suggested by the presence of Dansgaard/ Oeschger events in speleothems from nearby Goshute Cave, Nevada [Denniston et al., 2007]. In contrast, the DH T-II record is from $1 \mathrm{~cm}$ of vein calcite deposited from groundwater that traveled 80 to $>160 \mathrm{~km}$ through a regional aquifer over several millennia. On the other hand, LC-2 is limited by its short duration. For instance, as LC-2 does not record the onset of warming, it is possible that LC-2 captures only the latter part of the termination and thus underestimates the age of T-II. We emphasize that this is an important uncertainty and cannot be discounted without more speleothem records from this region. Nonetheless, the DH record levels off at interglacial values at or before (when accounting for groundwater transit time) the onset of the $2 \%$ shift in LC-2 at $133.5 \mathrm{ka}$, pointing to what are perhaps irreconcilable differences between the records if both are interpreted to record the timing of changes in the isotopic composition of precipitation. With the data at hand, we cannot resolve the apparent discrepancy between LC-2 and DH and leave this issue to future research.

\subsection{Devils Hole Interpretation}

[8] We turn now to the interpretation of the DH record. Much of our discussion focuses on T-I given the large number of well-dated records from this interval. DH also shows an early timing for this termination relative to insolation and sea level (Figures $3 \mathrm{j}$ and $3 \mathrm{k}$ ), with a $\sim 1 \%$ o increase from 27-17 ka (Figure 3h) [Winograd et al., 2006], 
suggesting that insights gained from T-I may apply to T-II as well.

[9] While DH was originally interpreted as a record of global glacial cycles [Winograd et al., 1988, 1992], it is generally now thought to be linked to Pacific SSTs via an atmospheric teleconnection [Herbert et al., 2001; Lea et al., 2000; Winograd et al., 1997, 2006]. Compelling evidence for this interpretation was first presented by Herbert et al. [2001]. They developed alkenone-based SST records along the western margin of North America spanning the past several glacial cycles and found that warming at more northerly sites preceded global deglaciation, as recorded by benthic $\delta^{18} \mathrm{O}$, by $\sim 10-15 \mathrm{kyr}$ during terminations. They suggested that $\mathrm{DH}$ records this anomalous early warming of the northeast Pacific and thus provides a record of regional, but not global, significance. While attractive, this interpretation has some drawbacks. Perhaps most important, California margin alkenone and foram-based SST records diverge during T-I, raising some questions over the reliability of these proxies during terminations [Hendy, 2010]. There are also some notable disagreements between the alkenone records and $\mathrm{DH}$. First, during T-II the SST records begin warming at $\sim 145 \mathrm{ka}$ on their orbitally tuned benthic $\delta^{18} \mathrm{O}$ chronologies, which lags behind initial warming in the $\mathrm{DH}$ record by 5-10 kyr. This lag is likely even longer when considering that the $\mathrm{DH}$ record must be shifted older to account for groundwater transit time and the SST records should perhaps be shifted younger as terminations in Pacific benthic $\delta^{18} \mathrm{O}$ may be delayed by several kyr [Lisiecki and Raymo, 2009; Skinner and Shackleton, 2005]. Second, SST records show a two-step warming pattern over T-II (ODP 1012 and 1020 [Herbert et al., 2001]; ODP 1014 [Yamamoto et al., 2004]), in contrast to the smooth termination in the $\mathrm{DH}$ record. Third, the $\mathrm{DH}$ record plateaus after $17 \mathrm{ka}$ during $\mathrm{T}-\mathrm{I}$ despite the $\sim 1 \%$ decrease in seawater $\delta^{18} \mathrm{O}$ associated with ice-sheet melting [Adkins et al., 2002]. This ice-volume effect is apparently masked in the DH record by warming of equal and opposite magnitude. No such warming is evident in the alkenone records, however. We return to this issue below.

[10] Winograd et al. [2006] extended Herbert et al.'s [2001] interpretation, suggesting that DH is associated with early warming of Pacific SSTs not just in the northeast part of the basin, but perhaps also in the tropics [Lea et al., 2000] or even in both hemispheres of the Pacific. They point to high correlations (r) of $0.66-0.83$ over the last glacial cycle between $\mathrm{DH}$ and several SST records from $2-41^{\circ} \mathrm{N}$ in the eastern Pacific as evidence of this linkage. We suggest that these correlations are largely a function of the strong 100-kyr signal present in most paleoclimate records of the last glacial cycle and may not necessarily imply that the early warming in $\mathrm{DH}$ during terminations is related to Pacific SSTs. For example, we obtain similar correlations between $\mathrm{DH}$ and the following records that do not display early terminations using the same approach as Winograd et al. [2006] (i.e., 160-4.5 ka window, a common $1.7 \mathrm{kyr}$ time step): LR04 benthic $\delta^{18} \mathrm{O},-0.50$ [Lisiecki and Raymo, 2005]; Vostok $\mathrm{CO}_{2}, 0.62$ [Petit et al., 1999]; Dome $\mathrm{C} \delta \mathrm{D}$, 0.72 [EPICA Community Members, 2004]; Aghulas core MD962077 SSTs, 0.85 [Bard and Rickaby, 2009]. We also use the leading principal components of radiocarbon-dated, high-resolution SST records of T-I from several regions of the Pacific (P. U. Clark et al., Global climate evolution during the last deglaciation, submitted to Nature Geoscience,
2011) to determine if and/or how DH is related to large-scale modes of SST variability. The PC1s account for 53, 44, 84, and $81 \%$ of the variance in the North $(\mathrm{n}=8)$, eastern tropical $(\mathrm{n}=9)$, western tropical $(\mathrm{n}=11)$, and South $(\mathrm{n}=8)$ Pacific, while the PC2s explain 19, 27, 5, and $8 \%$ of the variance in these regions. All of the PC1s are dominated by the deglacial warming signal from 20-11 ka (Figure 3b), and the PC2s display millennial-scale oscillations similar to the Heinrich 1-Bolling/Allerod-Younger Dryas sequence in the North Atlantic. DH, on the other hand, exhibits a steep rise from 19-17 ka followed by a plateau extending to the midHolocene (Figure $3 \mathrm{~h}$ ). Thus, DH appears largely unrelated to the two leading modes of SST variability during T-I around the Pacific, which together account for 71 to $89 \%$ of the variance in these areas.

[11] Regardless of its driver or spatial significance, the $\mathrm{DH}$ record is fundamentally interpreted as a record of isotopes in precipitation in the Great Basin. If it provides an at least regionally representative climate record, we would expect other continental records, particularly those also recording isotopes in precipitation, to display similar signals. On the contrary, various proxy records from around the western U.S., including lake sediments [Benson, 2003] and glaciers [Clark et al., 2009], disagree with the early timing for T-I and instead place the regional termination in phase with the global deglaciation. More significantly, two speleothem records from Arizona and New Mexico bear little resemblance to $\mathrm{DH}$ on the timing and structure of T-I (Figure $3 \mathrm{~g}$ ). The speleothems are in phase with the global deglaciation and are apparently more strongly related to Atlantic than Pacific forcing, with both exhibiting pronounced millennial variability associated with the BøllingAllerød and Younger Dryas events in the North Atlantic [Asmerom et al., 2010; Wagner et al., 2010]. These southwestern speleothems are in fact better correlated with distant speleothem and ice core records of T-I than with the nearby $\mathrm{DH}$ record, as seems to also be the case with stalagmite LC-2 during T-II (Figure 3). Lastly, oxygen isotopes in radiocarbondated groundwaters from southern Nevada record T-I from roughly 20-11 ka [Benson and Klieforth, 1989], well after the termination in DH. Thus, DH disagrees with various landbased climate records from the region during T-I, much as it seems to with LC-2 during T-II.

\subsection{Devils Hole Ice-Volume Correction}

[12] $\mathrm{DH}$, as any isotopic record, is subject to overprinting by changes in the oxygen isotopic composition of the ocean associated with variations in global ice volume. At times when $\mathrm{DH}$ diverges from the marine $\delta^{18} \mathrm{O}$ record during terminations, this effect may be particularly pronounced. We use an inverse ice-sheet model reconstruction of seawater $\delta^{18} \mathrm{O}$ to correct the $\mathrm{DH}$ record for changes in ice volume during the last two terminations (Figure 3h) [Bintanja and van de Wal, 2008] We use the originally published age model for this reconstruction, and do not account for the groundwater transit time of the ice-volume signal through the Devils Hole aquifer or for possible local seawater $\delta^{18} \mathrm{O}$ changes in the Devils Hole vapor source region. During T-II, this ice-volume correction slightly dampens the initial rise in $\mathrm{DH} \delta^{18} \mathrm{O}$, and more significantly, extends the termination by $\sim 7 \mathrm{kyr}$, thus delaying the onset of peak interglacial conditions until $\sim 127 \mathrm{ka}$. This lengthened termination may help bring $\mathrm{DH}$ into better agreement with our LC-2 stalagmite 
record, although the $\delta^{18} \mathrm{O}$ shift in LC-2 would still be many times larger than in $\mathrm{DH}$ during their period of overlap. T-I is similarly affected. The gradual early warming in $\mathrm{DH}$ becomes more muted and most of the deglacial rise now occurs from $\sim 19-11 \mathrm{ka}$, or in phase with the global sea-level rise and SST warming (Figures $3 \mathrm{~b}$ and $3 \mathrm{k}$ ). If this admittedly simple ice-volume correction is reasonably accurate, therefore, DH's depiction of terminations and interglacials may require some reconsideration [Winograd et al., 1997]. We acknowledge, however, that while this correction brings DH into general synchrony with the global deglaciation during T-I, the much-discussed onset of T-II in DH still begins much earlier than would be expected from classic Milankovitch forcing.

\section{Conclusions}

[13] In summary, our brief speleothem record of T-II from Lehman Caves, Nevada, appears to disagree with the nearby $\mathrm{DH}$ vein calcite record, as do other regional climate records during T-I. We also find that correcting the $\mathrm{DH}$ record for changes in seawater $\delta^{18} \mathrm{O}$ may affect its portrayal of terminations and interglacials, although the early onset of T-II in $\mathrm{DH}$ remains robust. We suggest that the interpretation of the DH record remains an open question and awaits the development of additional Great Basin speleothem records.

[14] Acknowledgments. We thank Matt Reece, Gretchen Baker, Ben Roberts, and Great Basin National Park for permission and help in collecting speleothems and Victor Polyak and Yemane Asmerom for providing preliminary dates on LC-2. Alan Mix and Rhawn Denniston provided helpful discussion, and three anonymous reviewers helped strengthen the original manuscript. J.D.S. is supported by a NOAA Climate and Global Change Postdoctoral Fellowship. Research supported by the National Science Foundation Paleoclimate Program.

[15] The Editor thanks the anonymous reviewer for their assistance in evaluating this paper.

\section{References}

Adkins, J., K. McIntyre, and D. P. Schrag (2002), The salinity, temperature, and $\delta^{18} \mathrm{O}$ of the glacial deep ocean, Science, 298, 1769-1773, doi:10.1126/science.1076252.

Asmerom, Y., V. J. Polyak, and S. J. Burns (2010), Variable winter moisture in the southwestern United States linked to rapid glacial climate shifts, Nat. Geosci., 3, 114-117, doi:10.1038/ngeo754.

Bard, E., and R. E. M. Rickaby (2009), Migration of the subtropical front as a modulator of glacial climate, Nature, 460, 380-383, doi:10.1038/ nature08189.

Bar-Matthews, M., A. Ayalon, M. Gilmour, A. Matthews, and C. J. Hawkesworth (2003), Sea-land oxygen isotopic relationships from planktonic foraminifera and speleothems in the eastern Mediterranean region and their implication for paleorainfall during interglacial intervals, Geochim. Cosmochim. Acta, 67, 3181-3199, doi:10.1016/S0016-7037(02)01031-1.

Benson, L. (2003), Western lakes, in The Quaternary Period in the United States, edited by A. Gillespie, S. Porter, and B. F. Atwater, pp. 185-204, Elsevier, Oxford, U. K.

Benson, L. V., and H. E. Klieforth (1989), Stable isotopes in precipitation and ground water in the Yucca Mountain region, southern Nevada: Paleoclimatic implications, in Aspects of Climate Variability in the Pacific and Western Americas, Geophys. Monogr. Ser., vol. 55, edited by D. H. Peterson, pp. 41-59, AGU, Washington, D. C.

Bintanja, R., and R. S. W. van de Wal (2008), North American ice-sheet dynamics and the onset of 100,000-year glacial cycles, Nature, 454, 869-872, doi:10.1038/nature07158.

Bowen, G. J., J. R. Ehleringer, L. A. Chesson, E. Stange, and T. E. Cerling (2007), Stable isotope ratios of tap water in the contiguous United States, Water Resour. Res., 43, W03419, doi:10.1029/2006WR005186.

Broecker, W. S. (1992), Upset for Milankovitch theory, Nature, 359, 779-780, doi:10.1038/359779a0.

Cheng, H., R. L. Edwards, Y. Wang, X. Kong, Y. Ming, M. J. Kelly, X. Wang, and C. D. Gallup (2006), A penultimate glacial monsoon record from Hulu Cave and two-phase glacial terminations, Geology, 34, 217-220, doi:10.1130/G22289.1.

Cheng, H., R. L. Edwards, W. S. Broecker, G. H. Denton, X. Kong, Y. Wang, R. Zhang, and X. Wang (2009), Ice Age terminations, Science, 326, 248-252, doi:10.1126/science.1177840.

Clark, P. U., A. S. Dyke, J. D. Shakun, A. E. Carlson, J. Clark, B. Wohlfarth, J. X. Mitrovica, S. W. Hostetler, and A. M. McCabe (2009), The Last Glacial Maximum, Science, 325, 710-714, doi:10.1126/science.1172873. Denniston, R. F., Y. Asmerom, V. Polyak, J. A. Dorale, S. J. Carpenter, C. Trodick, B. Hoye, and L. A. González (2007), Synchronous millennialscale climatic changes in the Great Basin and the North Atlantic during the last interglacial, Geology, 35, 619-622, doi:10.1130/G23445A.1.

Drysdale, R. N., J. C. Hellstrom, G. Zanchetta, A. E. Fallick, M. F. Sanchez Goni, I. Couchoud, J. McDonald, R. Maas, G. Lohmann, and I. Isola (2009), Evidence for obliquity forcing of glacial Termination II, Science, 325, 1527-1531, doi:10.1126/science.1170371.

Dykoski, C. A., R. L. Edwards, H. Cheng, D. Yuan, Y. Cai, M. Zhang, Y. Lin, J. Qing, Z. An, and J. Revenaugh (2005), A high-resolution, absolute-dated Holocene and deglacial Asian monsoon record from Dongge Cave, China, Earth Planet. Sci. Lett., 233, 71-86, doi:10.1016/ j.eps1.2005.01.036.

Edwards, R. L., and C. D. Gallup (1993), Dating of the Devils Hole calcite vein: Comment, Science, 259, 1626, doi:10.1126/science.259.5101.1626.

Emiliani, C. (1993), Milankovitch theory verified, Nature, 364, 583-584, doi:10.1038/364583a0.

EPICA Community Members (2004), Eight glacial cycles from an Antarctic ice core, Nature, 429, 623-628, doi:10.1038/nature02599.

Hendy, I. L. (2010), The paleoclimatic response of the Southern Californian Margin to the rapid climate change of the last $60 \mathrm{ka}$ : A regional overview, Quat. Int., 215, 62-73, doi:10.1016/j.quaint.2009.06.009.

Herbert, T. D., J. D. Schuffert, D. Andreasen, L. Heusser, M. Lyle, A. Mix, A. C. Ravelo, L. D. Stott, and J. C. Herguera (2001), Collapse of the California Current during glacial maxima linked to climate change of land, Science, 293, 71-76, doi:10.1126/science.1059209.

Herbert, T. D., J. D. Schuffert, D. Andreasen, L. Heusser, M. Lyle, A. Mix, A. C. Ravelo, L. D. Stott, and J. C. Herguera (2002), The California Current, Devils Hole, and Pleistocene climate: Response, Science, 296, 7, doi:10.1126/science.296.5565.7a.

Huybers, P., and C. Wunsch (2004), A depth-derived Pleistocene age model: Uncertainty estimates, sedimentation variability, and nonlinear climate change, Paleoceanography, 19, PA1028, doi:10.1029/2002PA000857.

Imbrie, J., J. D. Hays, D. G. Martinson, A. McIntyre, A. C. Mix, J. J. Morley, N. G. Pisias, W. L. Prell, and N. J. Shackleton (1984), The orbital theory of the Pleistocene climate: Support from a revised chronology of the marine $\delta^{18} \mathrm{O}$ record, in Milankovitch and Climate, vol. 1, edited by A. L. Berger, pp. 269-305, D. Reidel, Dordrecht, Netherlands.

Imbrie, J., A. C. Mix, and D. Martinson (1993), Milankovitch theory viewed from Devils Hole, Nature, 363, 531-533, doi:10.1038/363531a0.

Johnson, R. G., and H. E. Wright (1989), Great Basin calcite vein and the Pleistocene time scale: Comment, Science, 246, 262, doi:10.1126/ science.246.4927.262.

Karner, D. B., and R. A. Muller (2000), A causality problem for Milankovitch, Science, 288, 2143-2144, doi:10.1126/science.288.5474.2143.

Kawamura, K., et al. (2007), Northern Hemisphere forcing of climatic cycles in Antarctica over the past 360,000 years, Nature, 448, 912-916, doi:10.1038/nature06015.

Kelly, M. J., R. L. Edwards, H. Cheng, D. Yuan, Y. Cai, M. Zhang, Y. Lin, and Z. An (2006), High resolution characterization of the Asian monsoon between 146,000 and 99,000 years B.P. from Dongge Cave, China and global correlation of events surrounding Termination II, Palaeogeogr. Palaeoclimatol. Palaeoecol., 236, 20-38, doi:10.1016/j.palaeo.2005. 11.042 .

Landwehr, J. M., I. J. Winograd, and T. B. Coplen (1994), No verification for Milankovitch, Nature, 368, 594, doi:10.1038/368594a0.

Laskar, J., P. Robutel, F. Joutel, M. Gastineau, A. C. M. Correia, and B. Levrard (2004), A long term numerical solution for the insolation quantities of the Earth, Astron. Astrophys., 428, 261-285, doi:10.1051/ 0004-6361:20041335.

Lea, D. W., D. K. Pak, and H. J. Spero (2000), Climate impact of late Quaternary equatorial Pacific sea surface temperature variations, Science, 289, 1719-1724, doi:10.1126/science.289.5485.1719.

Lisiecki, L. E., and M. E. Raymo (2005), A Pliocene-Pleistocene stack of 57 globally distributed benthic $\delta^{18} \mathrm{O}$ records, Paleoceanography, 20, PA1003, doi:10.1029/2004PA001071.

Lisiecki, L. R., and M. E. Raymo (2009), Diachronous benthic $\delta^{18} \mathrm{O}$ responses during late Pleistocene terminations, Paleoceanography, 24, PA3210, doi:10.1029/2009PA001732.

Ludwig, K. R., K. R. Simmons, I. J. Winograd, B. Szabo, and A. C. Riggs (1993), Dating of the Devils Hole calcite vein: Response, Science, 259, 1626-1627, doi:10.1126/science.259.5101.1626-a. 
Petit, J. R., et al. (1999), Climate and atmospheric history of the past 420,000 years from the Vostok ice core, Antarctica, Nature, 399, 429-436, doi:10.1038/20859.

Skinner, L. C., and N. J. Shackleton (2005), An Atlantic lead over Pacific deep-water change across Termination I: Implications for the application of the marine isotope stage stratigraphy, Quat. Sci. Rev., 24, 571-580, doi:10.1016/j.quascirev.2004.11.008.

Thomas, A. L., G. M. Henderson, P. Deschamps, Y. Yokoyama, A. J. Mason, E. Bard, B. Hamelin, N. Durand, and G. Camoin (2009), Penultimate deglacial sea-level timing from uranium/thorium dating of Tahitian corals, Science, 324, 1186-1189, doi:10.1126/science.1168754.

Wagner, J. D. M., J. E. Cole, J. W. Beck, P. J. Patchett, G. M. Henderson, and H. R. Barnett (2010), Moisture variability in the southwestern United States linked to abrupt glacial climate change, Nat. Geosci., 3, 110-113, doi:10.1038/ngeo 707 .

Wang, Y. J., H. Cheng, R. L. Edwards, Z. S. An, Y. Wu, C.-C. Shen, and J. A. Dorale (2001), A high-resolution absolute-dated late Pleistocene monsoon record from Hulu Cave, China, Science, 294, 2345-2348, doi:10.1126/science.1064618.

Winograd, I. J. (2002), The California Current, Devils Hole, and Pleistocene climate, Science, 296, 7, doi:10.1126/science.296.5565.7a.

Winograd, I. J., and T. B. Coplen (1989), Great Basin calcite vein and the Pleistocene time scale: Response, Science, 246, 262-263, doi:10.1126/ science.246.4927.262-a.

Winograd, I. J., B. J. Szabo, T. B. Coplen, and A. C. Riggs (1988), A 250,000-year climatic record from Great Basin vein calcite: Implications for Milankovitch theory, Science, 242, 1275-1280, doi:10.1126/science. 242.4883.1275.

Winograd, I. J., T. B. Coplen, J. M. Landwehr, A. C. Riggs, K. R. Ludwig, B. J. Szabo, P. T. Kolesar, and K. M. Revesz (1992), Continuous 500,000 -year climate record from vein calcite in Devils Hole, Nevada, Science, 258, 255-260, doi:10.1126/science.258.5080.255.

Winograd, I. J., J. M. Landwehr, K. R. Ludwig, T. B. Coplen, and A. C. Riggs (1997), Duration and structure of the past four interglaciations, Quat. Res., 48, 141-154, doi:10.1006/qres.1997.1918.

Winograd, I. J., J. M. Landwehr, T. B. Coplen, W. D. Sharp, A. C. Riggs, K. R. Ludwig, and P. T. Kolesar (2006), Devils Hole, Nevada, $\delta^{18} \mathrm{O}$ record extended to the mid-Holocene, Quat. Res., 66, 202-212, doi:10.1016/j.yqres.2006.06.003.

Yamamoto, M., T. Oba, J. Shimamune, and T. Ueshima (2004), Orbitalscale antiphase variation of sea surface temperature in mid-latitude North Pacific margins during the last 145,000 years, Geophys. Res. Lett., 31, L16311, doi:10.1029/2004GL020138.

S. J. Burns, Department of Geosciences, University of Massachusetts Amherst, Amherst, MA 01003, USA.

H. Cheng and R. L. Edwards, Department of Geology and Geophysics, University of Minnesota, Twin Cities, Minneapolis, MN 55455, USA.

P. U. Clark, Department of Geosciences, Oregon State University, Corvallis, OR 97331, USA.

J. D. Shakun, Department of Earth and Planetary Sciences, Harvard University, Cambridge, MA 02138, USA. (shakun@fas.harvard.edu) 